\title{
Dogmatismo e Antidogmatismo: Kant na sala de aula*
}

\author{
Rubens Rodrigues Torres Filho**
}

\begin{abstract}
"Kant, embora não tivesse usado a fórmula: não há objeto sem sujeito, explica, com a mesma decisão que Berkeley e eu, o mundo exterior, que se apresenta no espaço e no tempo, como mera representação do sujeito que conhece (...) Porém, toda a passagem da página 348-392 (dos Paralogismos da Razão Pura), onde ele expõe seu idealismo resoluto com extrema clareza, foi por ele suprimida na segunda edição e, ao invés disso, introduzida uma grande quantidade de declarações conflitantes. Com isso, o texto da Crítica da Razão Pura, tal como circulou do ano de 1787 até o ano de 1838 , tornou-se um texto desfigurado e pervertido e a Crítica tem sido um livro que se contradiz a si mesmo e cujo sentido, por isso mesmo, não podia ser totalmente claro e compreensível a ninguém. Os datalhes sobre isso, bem como minhas conjeturas sobre as razões e fraquezas que teriam podido mover Kant no desfiguramento de sua obra imortal, eu as expus numa carta ao professor Rosenkranz" (editor das obras completas de Kant). ${ }^{1}$
\end{abstract}

Eis aí, como exemplo, um trecho de Schopenhauer que dá bem a medida da opinião de muitos outros intérpretes da melhor qualidade (como Nietzsche, Heidegger, Horkheimer...): Kant, na segunda edição de sua obra, recua da genial radicalidade da primeira Crítica, para acomodar de volta a velha coisa em si dos dogmáticos e para poder, com os postulados da razão

\footnotetext{
* Para Maria Lúcia Cacciola. Texto publicado em "Tempo de filosofia". Revista Tempo Brasileiro, 91, 1987.

** Professor aposentado do Departamento de Filosofia da USP.
} 
prática, recuperar "pela porta dos fundos" os velhos preconceitos metafísicos - Deus, mundo em si, alma imortal - que a filosofia crítica parecia ter banido para sempre. O "demole-tudo", como foi chamado por Moses Mendelssohn, regenerou-se, revelando-se um modelo de bom comportamento? Ou o filósofo das luzes enredou-se afinal, apesar do esforço de sua empreitada crítica, nas malhas do obscurantismo ético-religioso? Sabe-se que para Schopenhauer - abstendo-se, neste ponto, da norma que manda "explicar os produtos da razão pura pela mera razão" - a mudança de governo, pela morte de Frederico o Grande, obrigou o velho e experimentado pensador a fazer essa segunda edição, reformada, da Crítica da Razão Pura (A:1781; B: 1787), adocicando sua virulência antidogmática

Há entretanto no Prefácio dessa segunda edição uma pasagem - aquela, que contém a célebre fórmula: "Tive que suprimir - ou "suspender"? (aufheben) - o saber para obter lugar para a crença" - que parece indicar, ao contrário: da parte de Kant, essa "recaída no dogmatismo" não ocorre nem com disfarce nem a contragosto, mas com intenção declarada - e o interesse pela preservação daqueles valores comanda o próprio projeto da crítica da razão e a conseqüente demolição da metafísica dogmática, esta sim "fonte de incredulidade". Nesse Prefácio, em que as modificações com relação à primeira edição são atribuídas, unicamente, à necessidade de esclarecer pontos obscuros e de encontrar uma exposição mais fiel ao pensamento original, há muitas passagens que podem ser lidas, isto sim, como uma espécie de prospecto promocional da Crítica, pondo em destaque as qualidades e a utilidade do produto oferecido ao leitor, mas é justamente aí que haverá lugar para uma reflexão sobre o que está em questão nos comentários aludidos - ou seja, o efeito da Crítica da razão sobre a cultura.

O trecho que nos interessa (B XXVII: Nun wollen wir annehmen... a B XXXI: ...allen nachteiligen Einfluss zu benehmen.) é uma dessas passagens, onde o autor está se incumbindo de mostrar que a Crítica, dando a medida de uma futura metafísica científica, permite deixar à posteridade um legado (Vermächtnis) que constitui "um presente nada desprezível". Vamos tentar, através de uma análise cuidadosa desse texto, pondo à mostra suas articulações internas e o "movimento" lógico da argumentação, indicar de que maneira esses proclamados "efeitos salutares" da crítica da razão estão, na própria intenção explícita de Kant, visceralmente imbricados com a natureza mesma da empreitada que conduziu a descoberta da filosofia transcendental. 
As técnicas da análise estrutural de texto, não obstante o rigor, o academicismo e as "finezas" que se costumam atribuir-lhe, obedecem a normas bastante simples. Toma-se um segmento do autor, seccionado de seu contexto em pontos que indiquem uma articulação aparentemente natural (parágrafo, capítulo, passo da argumentação), e procura-se explicá-lo internamente, isto é, com os próprios recursos que ele oferece. Unicamente esse segmento é colocado em tela: o contexto - assim como o restante da obra - ficam reduzidos, provisoriamente, à simples condição de gramática ou dicionário, a que se pode recorrer quando alguma exigência do texto o solicitar. O texto, nessa sua materialidade, será interrogado conceitualmente, e não tematicamente: não se procurará saber o que ele diz - muito menos o que o autor quis dizer - mas como ele funciona; não os conhecimentos ou informações de que ele seria "veículo" - eventualmente, a respeito do "pensamento do autor" - mas o que acontece nele. Uma etapa posterior - e bem distinta, que pressupõe o término dessa primeira abordagem aparentemente formal - é o comentário, em que então se discutirão as idéias construídas pelo texto que foi analisado e suas implicações mais gerais.

A primeira coisa que se nota (Ce qui frappe d'abord...), numa primeira abordagem deste texto, é que ele está construído, pelo menos na sua primeira parte, sobre aquele modelo de argumentação classicamente conhecido como apagógico - ou, como também se diz, per absurdum. Toma-se como aceite o contrário daquilo que se quer provar e mostra-se o absurdo, a contradição de suas conseqüência: "Admita-se (por hipótese, pois esta é a tradução do substantivo Annahme, formado a partir deste verbo annehmen) que a nossa distinção não tivesse sido feita. Então..."2

$\mathrm{Na}$ Quarta Seção do capítulo dedicado à Disciplina da Razão Pura, Kant caracteriza a demonstração apagógica pela contraposição com a "direta ou ostensiva" (A 789; B 817): consiste em "justificar suas afirmações através de refutar o contrário" (A 792; B 820) ou na tentativa de "chegar através da refutação do contrário ao conhecimento da verdade" (A 793; B 821). Mas essa caracterização é feita sempre num contexto negativo: faz 
parte da disciplina da razão pura "que suas demonstrações jamais devem ser apagógicas" (A 789; B 817); no uso transcendental da razão pura "não será permitido justificar..." (A 792; B 820), "não se pode chegar..." (A 793; B 821). É que esse modo de demonstração é "mais um recurso em caso de necessidade (Nothilfe) que um procedimento que dá satisfação a todos os propósitos da razão" e tem como única vantagem a de ser mais intuitivo, já que "a contradição traz sempre consigo mais clareza na representação" (A 790; B 818). Não oferecendo, "junto com a convicção da verdade, ao mesmo tempo a penetração nas fontes dela" (A 789; B 817), acaba se tornando o "enganoso prestígio" (Blendwerk) que entretém os admiradores da pretensa solidez das raciocinações dogmáticas.

Antes, porém, de acusar um autor de estar usando agora um procedimento que condena, observe-se o contexto em que isso acontece: neste Prefácio, escrito em 1797, seis anos depois da publicação do livro, Kant se propôs a apresentar novamente a obra a um público que a desconhece e, para isso, adotou como método tratar como se fosse mera hipótese a "revolução", análoga à de Copérnico, que no corpo do livro é efetivamente - e apoditicamente - desempenhada. Leia-se, nesse sentido, o final da nota sobre Copérnico (B XXII): "Estabeleço neste Prefácio a conversão (Umänderung) do modo de pensar, análoga a essa hipótese (copernicana), e que é exposta na Crítica, também tão-somente como hipótese, se bem que no próprio tratado ela seja demonstrada, a partir do feitio de nossas representações de espaço e tempo e dos conceitos elementares do entendimento, não hipotética, mas sim apoditicamente, apenas para tornar perceptíveis as primeiras tentativas de uma tal conversão, que são sempre hipotéticas." Dentro dos limites dessa opção expositiva, seria lícito, então, tirar proveito, provisoriamente, da qualidade intuitiva daquele segundo tipo de demonstração, de resto inaproveitável no interior da ciência mesma. Reservemos por enquanto esta observação, para retomá-la oportunamente, quando vier de novo ao caso, e passemos ao exame da primeira oração do texto em análise.

A estranheza mais notável, aqui, é que se fala de uma "distinção" ("tornada necessária por nossa Crítica") entre "as coisas" (Dinge) e "elas mesmas" (ebendenselbe, com a escolha do pronome que enfatiza, pela reduplicação - eben e selben, - o caráter de identidade). Pela operação que institui o ponto de vista trancendental, as coisas são distinguidas de si mesmas! A palavra alemã que se traduz por "distinção", Unterscheidung, é formada de tal meneira que seu equivalente literal daria algo como "interpar- 
tição" ou "entre-cisão" - intercala-se, entre as coisas e elas mesmas, uma separação, desloca-se (ou descola-se) sua coincidência consigo mesmas. O operador dessa distinção é a preposição als: de um lado as coisas als "objetos da experiência", de outro as mesmas als "coisas em si mesmas". Essa preposição (em inglês as; em latim qua; em grego hè), inexistente em português, significa "na condição de", "no sentido de", "entendidas como" ou "tomadas como". Por isso leremos mais adiante que a Crítica ensinou a tomar os objetos "em dupla significação". Já se vê que o assunto é a distinção que se tornou célebre, convencionalmente formulada: entre "fenômeno" e "coisa em si". Nosso texto indica que essa distinção, ou intercisão, é a problematização de uma identidade, aparentemente pacífica: a das "coisas em geral".

Isso tudo comenta apenas um segmento da primeira oração: a referência à distinção estabelecida pela filosofia crítica. A oração inteira está introduzindo a hipótese de que essa distinção não tivesse sido feita - e tirando uma primeira conqüência disso.

Antes de continuar a leitura nesse sentido, cabe agora um reparo.

A língua alemã culta, especialmente no caso destes primeiros textos filosóficos escritos no idioma e não mais em latim, costuma conservar, ao lado do termo estrangeiro tomado de empréstimo, a expressão vernácula equivalente, de formação purista, tecnicamente designada como: Lehnübersetzung. Kant, ingenuamente acusado de "escrever mal", sabe também tirar partido dessa dualidade, a serviço de matizes conceituais.

É o caso, por exemplo, da palavra que se traduz convencionalmente por "fenômeno": Kant introduziu, como neologismo técnico de especialista, o termo grego Phainomenon (literalmente: "o aparecível"), para opô-lo a Noumenon ("o inteligível"), no capítulo final da Analítica Transcendental, que tem essas duas palavras no título; fora disso, no restante do livro, ocorre, esmagadoramente, a castiça palavra Erscheinung, substantivo do verbo erscheinen (aparecer), pois, de fato, não havia sido conquistado ainda o conceito correlato de noumenon; não se sabia ainda que a coisa em si, inacessível ao conhecimento, é apenas inteligível. Assim a Ercheinung, que é propriamente o aparecimento daquele "aparecível", merece o correto comentário do intérprete e tradutor francês Louis Guillermit: "Seriam necessários, na verdade, três termos para traduzir Erscheinung: fenômeno, aparência e aparição (no sentido de aparição de um cometa, e não de: espectro ou visão)."’3 
O mesmo se dá com a palavra Objekt, emprestada do latim, e sua tradução teutônica Gegenstand, que temos de traduzir, ambas, indiferentemente por "objeto". Kant trata de dar, à primeira, um sentido mais abstrato, quase como se o Gegenstand fosse uma espécie do gênero Objekt. Outra distinção, fundamental para nós e que desaparece na tradução, é entre Ding (coisa, com um primeiro sentido etimológico de "instrumento") e Sache (que também se pode traduzir por "causa", "assunto" ou "questão" e entra, justamente, na composição da palavra Ursache: "causa", mas também, literalmente, "coisa originária").

Já se verá que não se trata de digressão. Se a distinção crítica não tivesse sido feita, "o princípio de causalidade (Kausalität) e, conseqüentemente, o mecanismo natural na determinação das mesmas teria de valer cabalmente a propósito de todas as coisa (Dingen) em geral tomadas como causas (Ursachen) eficientes". Se estou, com o metafísico, no puro reino das Sachen, onde cada causa tem de ser pensada como efeito de uma outra, sou obrigado a regredir na séria das Ursachen, em busa de uma incondicionada e inatingível Ur-Sache, sem jamais encontrar essa Causa Primeira que saciaria minha infinita aspiração. Pior que isso: ainda que conformado à finitude e resignado ao império irrestrito do mecanismo natural, eu não poderia sequer, no interior desses limetes, afirmar a liberdade de minha vontade. Seria preciso rivalizar com a causalidade absoluta, e não simplesmente obter, para afirmar o livre arbítrio, uma modesta (mas absurda) exceção.

É o assunto do período seguinte, em que justamente a liberdade é escolhida como exemplo (zum Beispiel) para continuar a argumentação. "A propósito de um e mesmo ser (ebendemselben), por exemplo a alma humana..."- tomada então como coisa (Ding) em geral, isto é, como o Sache em si mesma - eu não poderia afirmar ao mesmo tempo, sem contradição, a liberdade da sua vontade e sua sujeição à necessidade natural. No entanto, ninguém poderia, "sem prévia Crítica", deixar de tomar "a alma", nas duas afirmações que se contradizem, em uma e mesma (ebenderselben) significação. ${ }^{4} \mathrm{Na}$ falta daquela equivocidade interposta pela reflexão crítica entre o mesmo e ele mesmo, a "alma" terá de ser tomada univocamente, isto é para fazer valer uma expressão cara de Bento Prado Jr.: - sem nenhum "tremor semântico". A escolha, então, será iniludível: determinismo - negação completa da liberdade - ou contradição.

"Se, porém, a Crítica não errou" ao ensinar a equivocar o objeto, a variar a significação em que se pode tomá-lo (als Erscheinung, oder als 
Ding an sich selbst), se é apenas na primeira dessas duas significações que o Objekt será Gegenstand, que ele estará propriamente contraposto, anteposto, perante (entgegen) o sujeito, então... Aqui, a própria construção da frase põe à tona a estrutura hipotética, condicional, do argumento: Se... então (Wenn...so). As condições, essas, serão duas: $1^{\mathrm{a}}$ a crítica da razão está certa ao introduzir essa dupla significação, minando assim aquela equívoca univocidade do dogmático; $2^{\mathrm{a}}$ a Dedução das Categorias está correta ao demonstrar que os conceitos puros do entendimento (entre eles, o de causalidade) só se aplicam "às coisas tomadas no primeiro sentido".

$* * *$

Dos doze conceitos puros do entendimento - as categorias, cuja necessidade e universilidade, resgatadas do ceticismo, se demonstram a partir do fato de serem elas as condições de possibilidade da própria experiência, à custa, entretanto, da indissociável restrição de sua aplicação aos limites da experiência possível (ao sensível, ao fenômeno) - é muito freqüentemente a segunda das três categorias da Relação - "causalidade e dependência (causa e efeito)" - a escolhida por Kant, com predileção, para ilustrar suas referências à Analítica Trancendental e para argumentar a partir dela. Seja como lembrança da "advertência de David Hume", que atacava justamente nesse ponto a aptidão da razão para julgar sinteticamente a priori e, ao fazêlo, "interrompeu o sono dogmático" dele próprio5; seja por considerar a questão do vínculo causal necessário como o exemplo mais patente, perante o senso comum, do problema que se coloca com todos os conceitos que envolvem uma síntese a priori, é ao conceito da causalidade que Kant remete, habitualmente, para tirar conclusões que se estendem às categorias em geral. Aqui, melhor ainda, é justamente esse o conceito que vem a calhar.

Em relação a uma alma tomada como "coisa em geral" - o que equivale a imaginar dogmaticamente esse "ser" ou "ente" (Wesen) como uma dentre as "coisas em si mesmas", - querer dotá-la de uma vontade livre seria tentar abrir, na ordem universal da necessidade (da não-liberdade), governada pela lei de causa e efeito, uma injustificada exceção, em detrimento até, no limite, da própria legalidade dessa lei. 
Não é possível afirmar então a liberdade da vontade? Sim, e agora sem destituir a lei da causalidade da validade universal e necessária compatível com sua dignidade de conceito puro. Em lugar de infligir a essa lei uma exceção empírica, a descoberta de Kant consistirá em dotá-la de uma limitação transcendental. Sua validade vai ao infinito, até onde alcance a possibilidade da experiência: assim como o tempo e o espaço, ela é constitutiva, intrinsecamente, dessa possibilidade. O não-sensível, porém, o além-do-sensível (das Übersinnlich), as "coisas" que estão para lá da experiência possível, para além da natureza, - tà metà tà ph ysica! - excluem, por definição, a sua jurisdição. Inaparecíveis, puramente inteligíveis e incognoscíveis, como sujeitá-las às leis que regem a aparição e que o entendimento prescreve aos fenômenos (sem ter que aprender deles)?

Ora, entre esses Objekten supra-sensíveis, estão, de acordo com a frase imediatamente anterior ao nosso texto, "esses mesmos objetos (ebendieselben Gegenstände, que acabaram de ser referidos como 'meros objetos da experiência') tomados como (als) coisas em si mesmas" - que, nessa condição, "se bem que não possamos conhecê-los", precisamos "pelo menos poder pensar", para evitar o disparate "de que houvesse aparição sem algo que nela aparece". A esses mesmos objetos, assim, o entendimento não poderá ditar leis. "O princípio de causalidade só se refere a coisas tomadas no primeiro sentido, mas essas mesmas (ebendieselben), de acordo com a segunda siginificação, não lhe estão sujeitas." (B XXVII in fine). Essa segunda significação, esse matiz, esse ligeiro descolamento de si mesmo do Mesmo, irá então designar o mesmo como o inteiramente Outro. O Ser, pura posição? A Existência irredutível?

Duas condições, portanto, que o texto irá resumir, mais adiante, com exatidão, pondo em destaque a estreita conexão entre ambas: “(...) se tem lugar nossa distinção crítica de ambos os modos de representação (o sensível e o intelectual) e a limitação, daí proveniente, dos conceitos puros do entendimento e, conseqüentemente, também dos princípios que deles defluem." Entende-se: a limitação desses princípios - no caso, especificamente, da segunda Analogia da experiência: "Todas as mudanças acontecem segundo a lei da conexão de causa e efeito" (B 232) - ao modo sensivel de representação, e sua inaplicabilidade, de direito, ao supra-sensível, às "coisas em si mesmas".

Podemos, pois, retomar o Então que responde a esse $S e$. 
Ei-lo aqui, textual e literamente: “(...) então essa mesma (ebendieselben) vontade na aparição (nas ações visíveis) é pensada como (als) necessariamente conforme à lei natural e nessa medida não livre, e no entanto, por outro lado, como (als) pertencente a uma coisa em si, não sujeita àquela, conseqüentemente como livre, sem que nisto ocorra uma contradição." A esta última, tomada na segunda significação, pode-se agora aplicar, como uma luva, aquela fórmula: não a podendo conhecer, é possível pelo menos pensá-la. O não-contraditório é a própria definição do pensável. Mas, afinal, o que ganhamos com isso?

Aparentemente nada, ao que se saiba. Essa "minha alma, considerada por esse segundo lado," é "algo" que não posso conhecer "através de nenhuma razão especulativa (e menos ainda através de observação empírica)": não posso colocar sob esse conceito, para lhe servir de base (unterlegen), "nenhuma intuição". Pois, para conhecer a liberdade "como propriedade de um ser ao qual atribuo efeitos no mundo dos sentidos", seria preciso, impossivelmente, conhecer um tal ser "segundo sua existência, e no entanto não no tempo". Ante tal impossibilidade, de que adiante poder pensar a liberdade? E, neste ponto, é indispensável assinalar que Kant entende a liberdade stricto sensu: iniciativa absoluta, faculdade de dar início a uma série causal inteiramente nova, em frontal ruptura com a segunda Analogia da experiência. ${ }^{6}$ De que vale, nesses termos, a mera pensabilidade dela?

A resposta virá logo a seguir, sob a forma de uma nova suposição: "Suponha-se, agora, que a moral pressuponha necessariamente liberdade (no sentido mais rigoroso) como propriedade de nossa vontade, na medida em que aduz princípios práticos, originários, contidos em nossa razão como dados dela a priori, que, sem pressuposição da liberdade, seriam pura e simplesmente impossíveis". Lembremos apenas, para situar o novo tema, que o imperativo categórico, o mandamento que se exprime na fórmula "Tu deves pura e simplesmente...", só pode ter como destinatário, para fazer sentido, um ser racional dotado de vontade livre. O único interlocutor váli- 
do da lei moral, capaz de ouvir sua "voz", é o sujeito que se pressupõe livre, capaz de desprender-se da causalidade das inclinações para atender a esse seu mando incondicional.

Diante dessa pressuposição, "ou seja, a (pressuposição) moral”, dois casos seriam possíveis: a) que "a razão especulativa tivesse provado que essa (pressuposição) absolutamente não se deixa pensar"; b) que "a Crítica nos tivesse previamente instruído de nossa inevitável ignorância a respeito das coisas em si mesmas". No primeiro caso, a pressuposição da liberdade pela moral seria tão-simplesmente absurda, derrubada pela pressuposição contrária, do império irrestrito do mecanismo natural; no segundo caso - e esta seria a utilidade positiva da Crítica da razão pura - se deixaria pelo menos um espaço (para lá do fenômeno, no plano das incognoscíveis coisas em si) onde a pressuposição da liberdade teria pelo menos uma chance de valer. Assim se poderia resumir, brutalmente, a argumentação kantiana. Mas o próprio uso, ao correr do comentário, dessa expresão: "deixar um espaço" - deveria chamar a atenção para uma tópica mais refinada, presente no texto, e já anunciada algumas linhas mais acima pela escolha da expressão statt haben (literalmente: ter lugar) para referir-se à distinção crítica entre a representação sensível e a representação intelectual.

$$
\text { *** }
$$

Não são necessários maiores refinamentos heideggerianos para observar que "ter lugar" ou "encontrar lugar" (statt haben, stattfinden), mesmo no seu primeiro sentido de "ocorrer", envolve já a noção de ter ou encontrar (ocupar) seu (próprio) lugar, isto é, de legitimar-se; diríamos: ter cabimento. Ou para lembrar que, ao lado da desusada palavra Statt (lugar, sítio), que se conserva ainda em derivados como anstatt ou statt (preposição: em vez de, em lugar de), zustatten kommen (vir a calhar, ser útil), statthaft (decoroso, válido) etc, a língua alemã tem ainda, no mesmo sentido, estas outras três: Ort, Platz, Stelle - das quais a primeira é o étimo da palavra Erörterung (comumente traduzida por "discussão"), que é o nome que Kant dá a todo o desenvolvimento que acompanhamos até agora e, de resto, a mesma que dá título às diversas seções da Estética Transcendental, 
ali traduzida por expositio (B 38) e podendo ser "metafísica" ou "transcendental"; e a segunda, Platz, é palavra-chave da frase em que culminará todo esse desenvolvimento: “(...) suprimir o saber para obter Platz para a crença". Todas essas indicações deveriam bastar para guiar a leitura no interior de uma tópica muito precisa, que fará corresponder a uma limitação (ou "restrição": Einschränkung) - ou seja, a limitação da "razão especulativa" - um ampliamento (Erweiterung): o "ampliamento prático da razão pura".

Admitamos então que uma Erörterung - que é como Kant define o conjunto de sua argumentação neste texto - consiste no ato de localizar, de colocar (os conceitos) em seus devidos lugares. Se a distinção crítica entre o fenômeno e a coisa em si não tem cabimento, se essa inter-partição não cabe entre as coisas consideradas em si mesmas e elas mesmas tais como nos aparecem, então, ao atribuir à alma, tomada em um sentido só, os predicados de livre e de não-livre, eu incorro em uma contradição manifesta. O notável, aqui, é perceber que, a bem do rigor, não precisaríamos, no início de nossa análise, ter ido buscar fora do texto uma definição de argumentação apagógica, de que precisaríamos para explicá-lo. Ela está formulada aqui mesmo, com todas as letras, nos termos do nosso problema: aquela pressuposição "cujo contrário não contém contradição nenhuma" tem de ceder lugar (weichen, Platz einräumen) à pressuposição rival, se esta é uma afirmação "cujo contrário contém uma contradição manifesta" (B XXIX).

Esse conflito dialético, essa disputa de "espaço vital" entre duas afirmações opostas - eco fiel da Terceira Antinomia - é justamente o que ocorre entre a afirmação da liberdade, exigida pela moral, e a afirmação do mecanismo natural - " tudo no mundo acontece exclusivamente segundo leis da natureza (A 445; B 473).

Sabe-se que as duas antinomias dinâmicas da Dialética Trancendental (a terceira e a quarta) nascem de uma confusão entre o fenômeno e a existência. Qual é, efetivamente, a diferença entre a fórmula recém-citada, que está no cabeçalho da Antítese da Terceira Antinomia, e o enunciado da segunda Analogia: "Todas as mudanças acontecem segundo a lei da conexão de causa e efeito"? Sem dúvida a mesma que levou Kant, ao propor, no § 17 dos Prolegômenos, uma escolha entre duas formulações perfeitamente equivalentes, a rejeitar aquela que se refere à legalidade das coisas como objetos da experiência: "tudo o que sabemos por experiência que acontece deve ter uma causa" - e a preferir aquela que se refere à legalidade da própria 
experiência: "sem a lei de que um acontecimento percebido é sempre referido a algo de antecedente, que ele segue segundo uma regra universal, um juízo de percepção nunca pode valer como experência." Só esta última fórmula evita o "mal-entendido" que me induziria a "imaginar que teria de falar da natureza como uma coisa em si." Esquecer que o princípio de causalidade vale unicamente como condição que torna possível a experiência e estendê-lo a "tudo no mundo": eis aí, justamente, o mecanismo da Ilusão transcendental, produto desse "imaginar".

A Dialética, como se sabe, é "a lógica da aparência", e a presença, lado a lado, da Tese ("A causalidade segundo leis da natureza não é a única...”) e da Antítese, a denuncia. Kant, no próprio texto que estamos analisando, oferecerá mais adiante uma frase lapidar para descrever esse mecanismo: a razão especulativa, na sua pretensão de conhecer o supra-sensível (o além da experiência), “é obrigada a servir-se de princípios tais, que, enquanto, de fato, só alcançam objetos de possível experiência, se mesmo assim são aplicados àquilo que não pode ser um objeto de experiência, efetivamente metamorfoseiam este, o tempo todo, em fenômeno (Erscheinung)."

(B XXX) Seria preciso reconhecermos aqui o esboçar-se de um primeiro gesto daquilo que a seguir fez época sob o nome de "crítica da reificação"?

Voltando, então, à seqüência do texto. Kant está supondo que a pressuposição do defensor da antítese tivesse mais força que a afirmação da liberdade. A razão especulativa teria conseguido provar que a causalidade por liberdade (atribuída a um ser intramundano) é impensável. Não se enredou nas malhas da dialética e foi capaz de tratar, legitimamente, "tudo no mundo" como "coisas em geral", obedientes à lei causal. O contrário de sua hipótese envolve, pois, apagogicamente, uma contradição manifesta. A prova da pressuposição contrária, a afirmação da "liberdade (no sentido mais rigoroso)", como requisito da moralidade, não podendo, por suposto, ser ostensiva, nem sequer pode ser agora apagógica: o contrário dela ("se não é já pressuposta liberdade") não contém contradição nenhuma. Só lhe resta, então, conceder lugar (einräumen, derivado de Raum, "espaço") para que se instale imperioso, o "mecanismo natural".

O que faz a Crítica, por sua vez, ao colocar às claras o caráter de pretensão (Anmaszung) desse triunfo da razão especulativa?

Desfaz a contradição. Nossa "inevitável ignorância a respeito das coisas em si mesmas", o inevitável enredar-se da razão pura em contradições dialéticas, tão logo pretenda transgredir os limites da experiência pos- 
sível, deixa de ser uma perda, recebida como uma triste notícia, para transformar-se numa "boa nova": "como, para a moral, nada mais preciso, a não ser que a liberdade tão-somente não se contradiga e, portanto, pelo menos se deixe pensar, sem ter necessidade de penetrá-la mais além" - e uma vez que a Crítica limitou "tudo o que nós podemos teoricamente conhecer a meros fenômenos" - então a liberdade "não coloca nenhum obstáculo no caminho do mecanismo natural de uma e mesma (ebenderselbem) ação". Desse modo, "a doutrina da moralidade afirma o seu lugar (Platz) e a doutrina da natureza também o seu."

Termina aqui o movimento dessa Erörterung: recolocados os conceitos em seus devidos lugares, a utilidade, aparentemente apenas negativa, da Crítica da Razão mostra o quanto tem de positivo. E aprendemos mais: a exposição, que agora se completa, a respeito do conceito de liberdade, é oferecida como um modelo. Sua eficácia é tríplice. Também os outros conceitos vitais para a moral - Deus, a imortalidade - poderiam ser preservados, resgatados do dogmatismo, pelo mesmo procedimento: "Esta mesma exposição (eben diese Erörterung) da utilidade positiva de princípios críticos da razão pura deixa-se mostrar a respeito do conceito de Deus e da $n a-$ tureza simples de nossa alma, que eu, porém, a bem da concisão, passo por alto." Não deixaria de ser um interessante exercício escolar aplicar, em classe, esse modelo a esses dois conceitos e experimentar assim uma Erörterung - nesse sentido que vimos - dos assuntos, respectivamente, da Quarta e da Segunda das Antinomias kantianas.

Vale a pena, neste ponto, passar a palavra a um convicto continuador de Kant, o jovem Fichte, que num de seus primeiros livros, sobre o conceito da "assim chamada filosofia", escreveu, no ano de 1794: "Colocar (erörtern) cientificamente um conceito (...) é como eu chamo, quando se indica seu lugar (Ort) no sistema das ciências humanas em geral, isto é, quando se mostra qual é o conceito que determina sua posição (Stelle) e qual outro tem a sua determindada por ele." ${ }^{\prime}$ Por isso costuma-se ligar a palavra erörtern, como termo técnico, ao latim determinare, no sentido lógico, em que Ort corresponderia a terminus (termo, término, limite).

A operação que vimos acontecer no texto de Kant consiste justamente em mostrar que a demarcação do território - a palavra alemã é Gebiet, "domínio", mas deve ser sempre entendida com o significado de "jurisdição", "circunscrição" ou "comarca", pois o verbo correspondente é gebieten, "ordenar", "comandar" - onde têm validade os conceitos e princípios puros 
do entendimento (as "leis da natureza") é o avesso do desimpedimento de um outro "território" (o além-do-sensível) para a possibilidade de uma outra e incomparável legalidade: a da lei moral. A aparente contradição desaparece quando se descobre que entre ambas não pode haver conflito de jurisdição.

Essa solução é formulada muito plasticamente, no nosso texto, por meio daquele famoso "jogo de palavras intraduzível" entre annehmen (admitir como hipótese, acolher, aceitar) e benehmen (retirar, tomar, confiscar), que exprime, justamente, o verso e o reverso dessa operação crítica, tornada possível por aquela distinção da "dupla significação". Se tentarmos reproduzir em português, a nível de significante, o efeito da frase, leremos algo como: "Eu não posso, portanto, nem sequer admitir Deus, liberdade e imortalidade, em vista do necessário uso prático de minha razão, se ao mesmo tempo não demito a razão especulativa de sua pretensão a conhecimentos transcendentes (Überschawengliche Einsichten)." Expressa aqui como simultaneidade (zugleich, "ao mesmo tempo"), é a complementaridade entre esse ponere e esse tollere que constitui a lição original da Crítica, a reversão pela qual sua utilidade negativa ("suprimir o saber" - bem entendido: lá no supra-sensível) se revela positiva ("obter lugar" - lá, também "para a crença").

A pretensão do dogmatismo de ampliar o saber para além dos limites de sua comarca, de alcançar, com o saber, o supra-sensível, consiste então em desnaturar esse supra-sensível, pois para isso ele é forçado a, inevitavelmente, naturalizá-lo. E se a Crítica da Razão Pura, mal compreendida, poderia, pelo fato de negar a possibilidade do conhecimento de Deus, da imortalidade e do livre arbítrio do homem, estar exposta a acusações de impiedade, seu autor pode agora, vitoriosamente, inverter essa acusação, numa frase tão conclusiva que vai até separada, do restante do parágrafo, por um travessão final: “(...) e o dogmatismo da metafísica, i.e. o preconceito de avançar nela sem crítica da razão pura, é a verdadeira fonte de toda incredulidade conflitante com a moralidade, (incredulidade esta) que é sempre muito dogmática. -"

Negar nosso conhecimento do supra-sensível é muito diferente de negar a existência dele: é reconhecer, criticamente, que tudo aquilo que podemos conhecer é mera "imagem sensível" - Erscheinung, na clássica tradução francesa de Tremesaygues/Pacaud - e, em conseqüencia, renunciar 
à pretensão de reduzir, sacrilegamente, aos nossos conceitos, aquilo que efetivamente $e$.

Por isso aquele mesmo Fiche, que se tornou célebre por ter rejeitado como absurda a expressão kantiana "coisa em si" e reabilitado, por sua vez, a proscrita "intuição intelectual", retomou, numa de suas últimas obras, a Lógica Trancendental de 1812, aquela questão da dupla significação, para consagrá-la como "a raiz e a mais íntima essência do órgão para a filosofia". É a consciência da distinção (Unterschied) entre ser e imagem: uma intuição toto genere diferente da consciência do "feitio qualitativo" da imagem, ou seja, de seu conteúdo - e na qual "não está dado um qualquer feitio, mas o inteiramente outro, o sentido, a significação em que se deve tomar (nehmen) o feitio; se se deve tomá-lo como (als) ser ou como (als) imagem." Esse "ter sentido para o sentido, como pura e simplesmente algo outro do que todo o possível que é tomado em um sentido" é, para Fichte, uma Einsicht (porém não überschwengliche), "sobre a qual repousa tudo", e que não se confunde com algum fantástico intuitus intelectualis de conteúdos supra-sensíveis. O criador da doutrina-da-ciência a atribui a Kant, como "a chama incendiante que já cedo o atingiu” e, para documentar sua presença, vai buscá-la no velho livro de 1763, O Único Fundamento Possivel para uma Demonstração da Existência de Deus: ali, "Kant diz: o ser não é um feitio, mas somente aquilo do qual são enunciados todos os feitios. Nesta última expressão, sem dúvida, ele imiscuiu de volta uma imagem-de-intuição, um substrato; e esse mau substrato é aquilo por amor do qual sua lição se perdeu." Pois Fichte, cioso da ortodoxia kantiana, continua a temer que, com isso, o ser propriamente dito - a existência em sua irredutibilidade - se preste ainda a ser confundido com uma imaginária e dogmática coisa em si, uma fantasmática "coisa" a ré do fenômeno, como uma assombração.

No restante do parágrafo, terminada aquela operação, triplicemente desdobrável, que abriu espaço para se acomodarem, um por um, os três postulados da razão prática - liberdade, Deus, imortalidade - subtraídos, doravante, à jurisdição da razão especulativa, o autor passará a uma simples enumeração dos benefícios futuros da Crítica da Razão, que fazem dela 
um valioso legado à posteriodade. Isso acontece em um único - e longo parágrafo, sob a forma de três ítens, dos quais os dois primeiros voltam a insistir em sua utilidade negativa - e propriamente "crítica" - e o terceiro, apresentado como o mais importante e, curiosamente, ligado aos anteriores pela forma adversativa ("maximamente porém..."), demora-se no comentário dessa sua conversão em positiva, pela capacidade de "pôr termo a todas as objeções contra a moralidade e a religião". Terceiro ítem que é o único, aliás, a merecer duas frases finais de explicitação, que serão o fecho do segmento que nos dispusemos a analisar.

Quais são, então, esses três efeitos benéficos que a crítica da razão pretende ter sobre a cultura em geral? O primeiro refere-se ao "cultivo da razão pela marcha segura de uma ciência"; o segundo, à "melhor aplicação do tempo de uma juventude ávida de saber". Nenhum deles, pois, revelando uma qualquer preocupação com a implantação da verdade do idealismo. São, sem dúvida, efeitos sobre a vida teórica, mas, de qualquer modo, vantagens decorrentes única e exclusivamente da demissão do dogmatismo. Podemos verificar isso pela simples leitura de sua formulação kantiana, que os destaca por contraste com a situação anterior, à qual a Crítica pôs termo:

$1^{\circ}(\ldots)$ quer se olhe meramente para o cultivo da razão pela marcha segura de uma ciência em geral, em comparação com o tatear sem fundamento e o leviano vagabundear dela sem crítica...

$2^{\circ}(\ldots)$ ou também para a melhor aplicação de tempo de uma juventude ávida de saber, que, junto ao habitual dogmatismo, obtém tão cedo e tanto encorajamento a sofismar (vernünfteln) comodamente sobre coisas das quais ela nada entende e nas quais ela, assim como ninguém no mundo, também nunca terá alguma penetração (nie etwas einsehen wird), ou até mesmo a partir para a invenção de novos pensamentos e opiniões, e assim negligenciar o aprendizado de ciências solidamente fundamentadas; (...)

Eis aí, pois, o nervo da utilidade negativa da Crítica: ter mostrado, definitivamente, que existem "coisas" nas quais "ninguém no mundo" pode penetrar com a visão (einsehen) - e banir para sempre a pretensão a essas Einsichten, que o dogmatismo costuma encorajar.

A seguir o texto parece tomar fôlego em sua enumeração, para encadear, agora, o terceiro efeito, este sim sobre a vida prática, e de resoluta 
positividade. Se no início a herança da Crítica era qualificada, por understatement, de "não desprezível", agora se poderá falar de uma vantagem "inestimável". E será introduzido no texto, sintomaticamente, o único nome de filósofo que nele comparece: o nome de Sócrates. Estará em questão, justamente, a força e a eficácia do "saber do não-saber". Colocado o pontoe-vírgula, Kant escreverá, então:

$3^{\circ}(\ldots)$ maximamente, porém, se se leva em consideração a inestimável vantagem de poder colocar um termo, por todo o tempo futuro, a todas as objeções contra a moralidade e a religião, de modo socrático, ou seja, através da mais clara demonstração da ignorância do oponente.

Que fazia o lendário Sócrates? Levava o interlocutor, "suposto saber", a contradizer-se, permanentemente, sem lhe oferecer em troca nenhum saber positivo. O que se pretende aqui, aparentemente, é oferecer aos pósteros uma espécie de ciência socrática, instituída e sistematizada, pronta para continuar funcionando pelo futuro todo. Se a Crítica da Razão Pura "teve futuro" - e é esse futuro dela que continuamos a viver até hoje - é para esse futuro que o autor, aqui, está voltando sua atenção. Por quê? Leiamos as duas últimas orações:

Pois uma qualquer metafísica sempre existiu no mundo e também continuará a existir sim, mas com ela também uma dialética da razão pura, porque lhe é natural, será encontrável dentro dela. É portanto o primeiro e mais importante interesse (Angelegenheit) da filosofia retirar-lhe (zu benehmen) de uma vez por todas, estancando a fonte dos erros, toda influência perniciosa.

Evita-se que a dialética natural da razão pura continua a exercer sua influência nociva desmascarando claramente essa dialética, que diz respeito, infelizmente, justo aos assuntos do máximo interesse humano. E mostrando que, sobre esses assuntos, "ninguém no mundo" pode ter nenhuma Einsicht. Com isso, estariam demolidos "Deus, a liberdade e a imortalidade"? Ou não estariam, pelo contrário, devolvidos a sua plena dignidade, como objetos de postulados práticos incondicionais?

Antes de pensar numa "recaída no dogmatismo", motivada, no velho Kant, por razões extra-filosóficas, é interessante, neste exato contexto, exa- 
minar aquela precoce interpretação da Crítica da Razão Pura engenhada pelo jovem Schelling num de seus primeiros livros, as Cartas sobre o Dogmatismo e o Criticismo de 1795.

Ali, embora se trate de um manifesto tomando partido, resolutamente, pelo "sistema do criticismo" (ou idealismo, com a afirmação da anterioridade absoluta do sujeito com relação ao objeto) e contra os "grilhões" do "dogmatismo" (ou realismo, com a absoluta afirmação simétrica da anterioridade do objeto), Schelling aponta para a igual possibilidade, simétrica e antinômica, desses dois "sistemas", inscrita na própria razão e teoricamente indecidível. Por isso é importante não confundir a Crítica da Razão Pura, que demonstrou definitivamente isso, com o sistema criticista ou "idealismo", que ela apenas tornou possível para o futuro. Ter mostrado que o antagonismo entre esses dois sistemas só é decidível pela razão prática, através de postulados indemonstráveis, não é decidi-lo a favor de nenhum dos dois lados. É apenas indicar em que campo e com que armas o combate deve ser legitimamente travado. Mais que isso, é fornecer, a ambos os oponentes, e também, portanto, ao novo dogmatismo com "prévia Crítica" idealizado por Schelling, o "método dos postulados práticos" como comum arsenal. Por isso, quando à questão histórica, bem diferente (e filosoficamente indiferente), de qual dos dois partidos Kant teria, pessoalmente, tomado, Schelling poderá, então, tranqüilamente escrever:

A Crítica, que estabeleceu aquele método dos postulados práticos para dois sistemas inteiramente opostos, impossivelmente podia ir além do mero método, impossivelmente podia, já que devia ser suficiente para todos os sistemas, determinar o espírito próprio desse método no sistema individualmente tomado. Precisava, para manter aquele método em sua universalidade, mantê-lo ao mesmo tempo naquela indeterminação que não excluía nenhum de ambos os sistemas. Até, conforme ao espírito de sua época, ele tinha de ser aplicado, pelo próprio Kant, antes ao sistema do dogmatismo novamente fundamentado, que ao sistema do criticismo, fundamentado por ele pela primeira vez. ${ }^{10}$ 
Este é, em linhas gerais, o esquema de uma aula que, perante uma classe pouco numerosa de História da Filosofia Moderna III, visava introduzir o tema do curso. A maneira sintética que foi obrigado a adotar, pela circunstância, para essa finalidade, levou o professor à ilusão de que isso poderia interessar a mais gente e, imitando o gesto de Antônio Candido, a dar uma forma escrita ao conteúdo da preleção, que pretendia tão-somente estabelecer alguns poucos pontos - de resto, bastante pacíficos - de um momento decisivo no desenvolvimento do pensamento ocidental. A preparação desta aula foi grandemente facilitada pela leitura de alguns ensaios de Gérard Lebrun, agora reunidos em livro com o título Era uma Vez em Königsberg (Brasiliense; no prelo).

(Universidade de S. Paulo, no $2^{\mathrm{o}}$ centenário da $2^{\mathrm{a}}$ edição da Crítica da Razão Pura, hin und wieder verbesserte.)

\section{Notas}

${ }^{1}$ Arthur Shopenhauer, Crítica da Filosofia Kantiana, trad. Maria Lúcia Cacciola, "Os Pensadores".

${ }^{2}$ Immanuel Kant, Kritik der reinen Vernunft, B XXVII. Não uso as traduções ambas igualmente sérias - de Rohden/Moosbuger e de Santos/Morujão apenas pela comodidade de lidar diretamente com o texto alemão de Kant, que se revela melhor assim a olho nu. (Na trad. Portuguesa, que não reproduz a paginação do original, o nosso texto vai da p. 25 à p. 28; Gulbenkian, 1985.)

${ }^{3}$ Louis Guillermit, trad. dos Progrès de la Métaphysique, Vrin, p. 123, citado por Gérard Lebrun, "A Aporética da Coisa em Si”, Cadernos de História e Filosofia da Ciência $\mathrm{n}^{\circ}$ 5, Campinas, 1983.

${ }^{4}$ Essa expressão "sem prévia Crítica" é quase um slogan, que comparece sempre como parte integrante da definição, justamente, do dogmatismo. Veja-se mais adiante, neste mesmo texto: "o dogmatismo da metafísica, i.e. o preconceito de avançar 
nela sem Crítica da razão pura" (B XXX); "sem prévia Crítica de sua própria capacidade..." (B XXV); "sem prévio exame da faculdade ou incapacidade..." (B 7).

${ }^{5}$ Prolegômenos a toda a Metafisica Futura, A 13, trad. Artur Morão, Edições 70, Lisboa, 1982.

${ }^{6}$ Basta conferir, quanto a isto, $K r V$ A 533; B 561: "a faculdade de iniciar por si (vonselbst) um estado, cuja causalidade, portanto, não está, por sua vez, segundo a lei da natureza, sob uma outra causa, a qual a determinasse segundo o tempo."

${ }^{7}$ Prolegômenos, A 76-77, trad. citada.

${ }^{8}$ Johann Gottlieb Fichte, Sobre o Conceito da Doutrina-da-ciencia ou da Assim Chamada Filosofia §3, S.W. I, 55; no vol. A Doutrina-da-ciência de 1794 e Outros Escritos, trad. RRTF, "Os Pensadores."

${ }^{9}$ Ueber das Verhältnisz der Logik zur Philosophie, oder transzcendetale Logik, N.W. I, 137-138.

${ }^{10}$ F.W.J. Von Schelling, Cartas Filosóficas sobre o Dogmatismo e o Criticismo, S.W.I, 303-304, trad. RRTF, "Os Pensadores". 